\title{
Susan Harris Rimmer and Kate Ogg (eds.): Research Handbook on Feminist Engagement with International Law \\ Lynsey Mitchell
}

This is a post-peer-review, pre-copyedit version of an article published in Feminist Legal Studies. The final authenticated version is available online at: https://doi.org/10.1007/s10691-019-09417-y 


\section{Susan Harris Rimmer and Kate Ogg (eds.): Research Handbook on Feminist Engagement with International Law \\ Edward Elgar Publishing, Cheltenham, ISBN: 20199781785363917}

Lynsey Mitchell

The editors of this ambitious handbook have successfully curated a collection of papers that seek to highlight the relevance and usefulness of feminism in international law. This collection showcases the breadth and depth of recent feminist engagements with international law, and as such seeks to position feminist approaches as both a tool and method of excavation within critical international legal scholarship. However, rather than merely offering a critique and summary of current and historical feminist legal scholarship, this collection provides a roadmap for using feminist legal methodologies to both engage in critiques of, and contribute alternative means of conceptualising, a whole host of international law disciplines as well as interdisciplinary legal issues.

From Charlesworth, Chinkin and Wright's seminal article 'Feminist Approaches to International Law' in 1991 (Charlesworth, Chinkin and Wright 1991), the introduction of the text under review notes that there has been an explosion in feminist literature in international law throughout the $1990 \mathrm{~s}$ and $2000 \mathrm{~s}$, all of which attempted to offer new perspectives and solutions to issues such as; human rights violations (Bunch 1990), humanitarian intervention (Engle 2007; Orford 2003), sexual violence during conflict (Gardam 1994; Mackinnon 1997), and the gendered nature of the international legal system itself (as well as a host of other issues that mainstream international law scholarship had tended to ignore). This 'explosion' of new perspectives, methods, and methodologies soon generated a series of edited collections that provided a summary and critique of the emerging discipline of feminist international law (Kouvo and Pearson 2011; Buss and Manji 2005). However, the editors of this collection concede that, despite this increase in feminist scholarship there has been little transformation outside the academy, which has led to 'a sense of pessimism' (2) 'despair' (2) and even a lingering unease that feminist perspectives are 'no longer in vogue' (8). Additionally, the editors also concede that, while attempting to challenge and dismantle dominant hierarchies in law, feminist legal scholarship has all too often been dominated by white Western feminists whose solutions and priorities have often alienated women of colour and non-Western scholars (Kapur 2002; Mutua 2001) leading to so called schisms and fractures within feminist 
scholarship. (7) These accusations have loomed large over feminist legal scholarship and in recent years had come to besiege the discourse.

Thus, in the introduction to this collection, the editors address head-on, these tensions within feminist legal scholarship. They acknowledge that much of this dissolution and disquiet stems from a sense of discomfort over the unintended consequences of feminist victories (2), as well pertinent criticism of the field's continued domination by Western feminists. This collection therefore engages directly with such debates and seeks to offer a path along which feminist scholarship can navigate. Situating themselves as guides steering the discipline out of this fog, the editors and contributors set themselves the task of looking to the future noting that "it is through future-gazing that we keep "feminist imagination and vision." (3). This ambitious collection successfully steers feminist debates in a new direction by consciously situating feminism as a tool for excavating inequality and rethinking structural hierarchies within law. In the foreword to The collection Hilary Charlesworth succinctly diagnoses how 'feminism's cluttered mix of utopian thought and critical thinking thus complicates the search for feminist futures' (xxv). Yet, by acknowledging the difficulties inherent in doing feminist research, and shifting the focus from a unified idea of what is and is not 'feminist', this collection breaks new ground.

The span of specialities within international law is impressive and as such the text under review offers a clear demonstration of the potential of feminist methods and theory to provide alternative and engaging ways of thinking about many of the current challenges in international law. The handbook is a product of two workshops convened by the editors in Brisbane and Geneva in 2016. The editors describe how they actively sought submissions that would push the boundaries of feminist scholarship beyond this internal wrangling and seek wider audiences through structuring discussion around themes such as cataclysm and rapture, abandonment, and normative victories that ring hollow (4). This collection appears to consciously move away from overly focussing on sexual violence, a charge that has dogged many feminist collections and the discourse itself. It is a deliberately provocative in its scope and subject matter, bringing feminist enquiry to bear on a wide variety of seemingly disparate issues, all the while highlighting the silences that the patriarchal legal system has too long ignored.

The handbook consists of four parts, each dedicated to a specific theme. Part one is titled Diversifying Feminist Engagement with International Law. This part speaks to some of the issues raised in the introduction and heads off the common criticism of adopting feminist approaches to international law, namely that feminists are often accused of 'talking to ourselves' (Charlesworth 2011, 23) rendering it a 'ghettoised' (Charlesworth 2001, 35) 
discipline. Indeed, critics have often suggested that due to the discipline's focus on wartime sexual violence, it is perceived as having little to say on supposedly 'masculine' areas of international law. Part one of this handbook directly addresses these criticisms by offering a diverse list of authors, some emerging and some firmly established, who consider a variety of fields such as wildlife, climate change, global constitutionalism, international disasters, and state aid from a feminist legal perspective. As well as offering innovative critiques of these individual fields, this part serves to demonstrate the usefulness and relevance of feminism to mainstream international law and lawyers. In addition to providing perspectives from a variety of legal, and non-legal scholars, the collection also offers practitioner perspectives. These reflect on the success and usefulness of feminist approaches in the International Labour Organisation, the courts, and in navigating the EU provisions on state aid, and provide a sense of how much feminist research and activism has achieved within international organisations, even if they acknowledge there is still work to be done.

Part two of the handbook is titled Making Feminist Engagement with International Law More Influential: Not just talking to ourselves. It sets out to engage with Charlesworth's concern that feminists are solely 'talking to ourselves' and in response puts forward a manifesto for integrating feminism and feminist legal methods in order to influence mainstream international law scholarship. This part offers contributions on refugee law, women and the international criminal court, international judging, human security, legal scholarship in the neoliberal university, and a practitioner perspective on international treaty making. This part provides a helpful acknowledgment of the gains made by feminist legal research in some areas. It further seeks to demonstrate how feminist engagement has had a transformative effect on international institutions. It also pushes the boundaries of feminist international legal research by posing questions on how to 'do law differently' (269) in the neo-liberal university and also revisiting the very 'category of woman' (240). It thereby deftly demonstrates the relevance and importance of feminist engagement in framing and understanding the challenges in contemporary international law and legal education in order to provide innovative and creative solutions and calls on feminist scholars to celebrate their contributions, while recognising that the discipline should remain dynamic and relevant.

Part three is titled Feminist Engagement with International Law: Improving women's Lives and draws heavily on socio-legal perspectives and covers topics such as economic inequalities, health and international law, oral history, socio-economic rights, feminist time, and a practitioner perspective on women's invisibility in criminal justice. This part continues the collection's overall aim of moving feminist engagements into unchartered territories of 
international law. The chapter on gender and health explicitly focusses on infectious disease outbreaks and the health system-strengthening agenda in the sustainable development goals, while noting that much of the scholarship on gender and health has focussed on sexual and reproductive rights and freedoms. Contributions such as this demonstrate how gendered approaches to health rights can be utilised to critique wider public health issues and offer better solutions, thereby continuing to demonstrate how feminist approaches are relevant to a variety of issues and should not just be conceptualised as serving only the ghetto of women's issues.

Part four is titled Building Bridges with Other Critical Theories. In this final part, the handbook seeks to redress a further criticism levelled at feminist scholars, which is that feminism cannot adequately address intersectional issues and thus leaves feminism unable to respond to current issues of importance at the boundaries of social justice. This part offers contributions that explore African culture, queering international human rights law, matri-legal feminism, third-world approaches to international law, and indigenous women. This part offers some diverse perspectives, but makes a concerted effort to situate these contributions as works that speak outwards to international lawyers and reflect on the discipline as a whole. The result is a vibrant section that invigorates the debate.

The collection concludes with an afterword written by Dianne Otto who celebrates the text for re-invigorating feminist scholarship in international law and embracing the challenges. She states that 'despite the success of some feminist efforts to promote change in international law, to make women's and ultimately everyone's, lives more fully liveable, our work has barely begun' (534). Otto succinctly describes the tentative optimism that volumes such as this should inspire. While there is much still to be done to situate feminist scholarship within mainstream international law and achieve the transformative potential to improve women's lives, this collection aims to re-centre the focus of feminist scholarship and de-ghettoize the discipline by offering considered engagement with other critical theories and the views of practitioners. As such, this collection can be viewed as a robust response to Janet Halley's rumination on whether we should 'take a break from feminism' (Halley 2008). Perhaps the period of reflection and critique on the future of the discipline might be considered as 'taking a break', and therefore collections such as this lend a momentum toward an invigorated and more challenging feminism within international law.

Like feminism, and feminist scholarship itself, this collection may be accused of speaking to a narrow audience and having appeal to those unfamiliar with feminist scholarship. That would be a deeply unfair criticism. This collection consciously steers into new territory 
and actively embraces contemporary global issues, perfectly demonstrating the breadth and depth of feminist thinking and its relevance and utility in reframing international law.

\section{References}

Bunch, Charlotte. 1990. Women's Rights as Human Rights: Toward a Revision of Human Rights. Human Rights Quarterly 12: 486-498.

Buss, Dorris and Ambreena Manji eds. 2005. International Law: Modern Feminist Approaches. Oxford: Hart Publishing.

Charlesworth, Hilary, Christine Chinkin and Shelly Wright. 1991. Feminist Approaches to International Law American Journal of International Law 85: 613-645.

Charlesworth, Hilary. 2001. The Women Question in International Law Asian Journal of International Law 1: 33-38.

Charlesworth, Hilary. 2011. Talking to Ourselves? Feminist Scholarship in International Law. In Feminist Perspectives on Contemporary International Law: Between Resistance and Compliance, ed. Sari Kouvo and Zoe Pearson, 17-32. Oxford: Hart Publishing.

Halley, Janet. 2008. Split Decisions: How and Why to Take a Break from Feminism. Princeton: Princeton University Press.

Kouvo, Sari and Zoe Pearson, eds. 2011. Feminist Perspectives on Contemporary International Law: Between Resistance and Compliance. London: Hart Publishing.

Engle, Karen. 2007. Calling in the Troops: The Uneasy Relationship among Women's Rights, Human Rights, and Humanitarian Intervention. Harvard Human Rights Journal 20: 189-226.

Gardam, Judith. 1997. Women and the Law of Armed Conflict: Why the Silence? International and Comparative Law Quarterly 46: 55-80.

Kapur, Ratna. 2002. The Tragedy of Victimization Rhetoric: Ressurecting the "Native" Subject in International/Post-Colonial Feminist Legal Politics Harvard Human Rights Journal 15: 1-38.

MacKinnon, Catharine. 1994. Rape, Genocide, and Women's Human Rights. Harvard Women's Law Journal 17: 5-16.

Mutua, Makau. 2001. Savages, Victims, and Saviors: The Metaphor of Human Rights. Harvard International Law Journal 42: 201-245.

Orford, Anne. 2003. Reading Humanitarian Intervention: Human Rights and the Use of Force in International Law. Cambridge: Cambridge University Press. 